\title{
新エネルギーキャリアとしての高容量 水素吸蔵合金
}

\author{
射場 英 紀沗 \\ 毛 利 敏 洋光 \\ 塩野谷美和子 3 \\ 秋葉悦男**
}

\section{1. は じめに}

地球環境問題の観点から，水素を利用したエネルギーシス テムが提案されている(1). 図1に示すよらにこのよらなシ ステムに打いては，太陽熱や水力などをエネルギー源とし， 電気, 熱, 水素を媒体としてェネルギ一を貯蔵・輸送し, 水 素エンジンや燃料電池などによってこれを消費して水を生成 する，そのため，従来の化石然料や原子力をべースにしたエ ネルギーシステムにくらべ，きわめて環境に対する負荷が小 さいと考光られる。

このようなシステムの中で，水素吸蔵合金は，電気・熱· 水素などのエネルギー媒体の貯蔵・輸送の手段，つまり，エ ネルギーキャリアとして，材料とアプリケーションの両面か ら研究がすすめられてきた。エネルギー貯蔵・輸送のアプリ ケーションとしては, その媒体ごとに水素の貯蔵タンク, 電 気の $\mathrm{Ni}-\mathrm{MH}$ 電池, 熱のヒートポンプと大別できる。この中 で，特に自動車に関連するものとしては，水素エシジン用の 燃料タンク，電気自動車用の $\mathrm{Ni}-\mathrm{MH}$ 電池などが試作されて きた。

図 2 は，水素吸蔵合金を用いた貯蔵タンクを搭載した水素 自動車の一例である(2)，表１には，この水素自動車の性能評 価をもとに，他の代替エネルギー車の性能と特性との比較を 示している. 水素自動車は, 他の代替ェネルギー車にくらべ て $\mathrm{HC}$ やO などのエミッションはほとんどなく環境負荷に 対しては優れるが，性能面では，合金の重量が大きいため十 分な航続距離を満足する合金量を搭載できないということが 問題である。

* トヨタ自動車株式会社

第 1 材料技術部金属材料室 1) スタッフリーダー 2)担当員 第 1 材料技術部分析課 3 ) 技術員

** 物質工学工業技術研究所

無機材料部無機機能設計室室長

Hydrogen Absorbing Alloys with High Capacity for New Energy Carrier: Hideki Iba*, Toshihiro Mouri*, Miwako Shionoya*, Etsuo Akiba**(*TOYOTA Motor Corporation, **National Institute of Materials and Chemical Research) 1997年 1 月 31 日受理
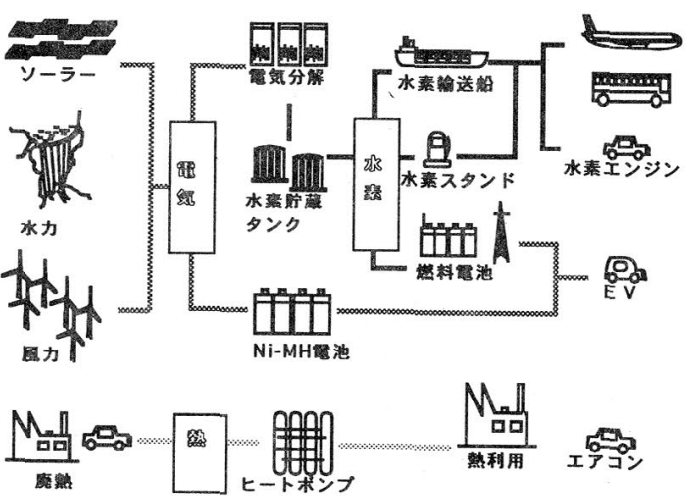

図1＼cjkstart新エネルギーキャリアとしての水素吸蔵合金.

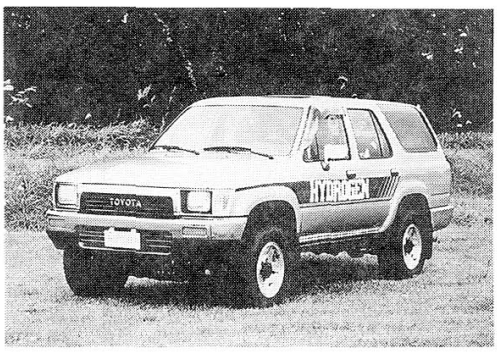

図 2 水素吸蔵合金タンクを搭載した水素自動車(試作 車).

図 3 は, Ni-MH 電池を搭載した電気自動車 $(\mathrm{EV})$ の一例で ある(2). 水素吸蔵合金を負極に用いた Ni-MH 電池は，従 来, 二次電池として用いられてきた鉛電池や Ni-Cd 電池に くらベェネルギー密度が大きく，これを用いることより，電 池の重量は大幅に軽量化できる。しかし，この場合もやはり 表 1 K示したようにガソリン車に比べると航続距離は十分 でなく, 今後の量産化のためには, さらなる電池の容量の増 大が望まれている。

このよらに, 水素ェンジン車, $\mathrm{Ni}-\mathrm{MH}$ 電池電気自動車, いずれに扣いても，水素タンクや電池の重量が大きく，これ らの重量を軽減することが, 今後の実用化や大量生産のため の一つの開発課題とされてきた.このような軽量化の手段と 
表 1 代替エネルギー車との性能と特性比較.

\begin{tabular}{|c|c|c|c|c|c|c|c|c|c|c|c|}
\hline & & $\mathrm{HC}$ & $\mathrm{CO}$ & NOx & $\begin{array}{l}\text { スモ } \\
-ク\end{array}$ & $\mathrm{CO}_{2}$ & 皆 & 勢 & $\begin{array}{l}\text { 航続 } \\
\text { 距離 }\end{array}$ & 特徵·現状 & 技術的課題 \\
\hline \multirow{3}{*}{$\begin{array}{l}\text { 現 } \\
\text { 徆 }\end{array}$} & ガソリン車 & 0 & 0 & 0 & 0 & 0 & 0 & 0 & 0 & 総合的なバランス良好 & \\
\hline & ディーゼル車 & O & 0 & $\triangle$ & $x$ & (a) & $\triangle$ & (C) & (a) & 燃費が良好・ $\mathrm{CO}_{2}$ 排出が少ない & $\begin{array}{l}\mathrm{NOx}, \text { パティキュレートの低 } \\
\text { 減 }\end{array}$ \\
\hline & LPG 車 & $\bigcirc$ & 0 & 0 & 0 & 0 & $\triangle$ & 0 & 0 & タクシーを中心に普及 & \\
\hline \multirow{6}{*}{$\begin{array}{c}\text { 代 } \\
\text { 替 } \\
\text { 工 } \\
\text { 不 } \\
\text { 足 } \\
\text { 列 } \\
\text { 車 }\end{array}$} & メタノール車 & $\bigcirc$ & $\bigcirc$ & 0 & $\bigcirc$ & O & 0 & O & $\triangle$ & $\begin{array}{l}\text { 石崖·炎然がスなどの各種の資 } \\
\text { 源が利用でさ }\end{array}$ & $\begin{array}{l}\text { アルデヒドの低減 } \\
\text { エンジン信頼性の向上 }\end{array}$ \\
\hline & 天然がス車 & O & 0 & 0 & 0 & 0 & 0 & 0 & $\triangle$ & $\mathrm{CO}_{2}$ 排出が少ない & 燃料搭載性の改善 \\
\hline & $\begin{array}{l}\text { 水素自動車 } \\
\text { (水素吸蔵合金) }\end{array}$ & (O) & (a) & 0 & (a) & (2) & $\triangle$ & O & $\times$ & クリーンな排出ガス & 燃料の製造・眝蔵技術の確立 \\
\hline & 電気自動車 & (a) & (a) & (C) & (C) & (C) & $\triangle$ & - & $x$ & クリーンな排出ガス & 高性能な電池の開発 \\
\hline & ソーラーカー & ()) & (2) & (0) & (C) & (0) & $x$ & - & $x$ & クリーンな排出ガス & 高性能な太陽電池の開発 \\
\hline & ガスタービン車 & 0 & 0 & $\triangle$ & O & 0 & 0 & 0 & $\triangle$ & 低振動·軽量·多燃料性 & 熱効率の向上 \\
\hline
\end{tabular}

・ガソリンエンジンをベースとして試算

・ $\mathrm{CO}_{2}$ 汇関しては然料製造段階での発生量は含まない. 航統距離は同一容積の燃料タンクでの比較

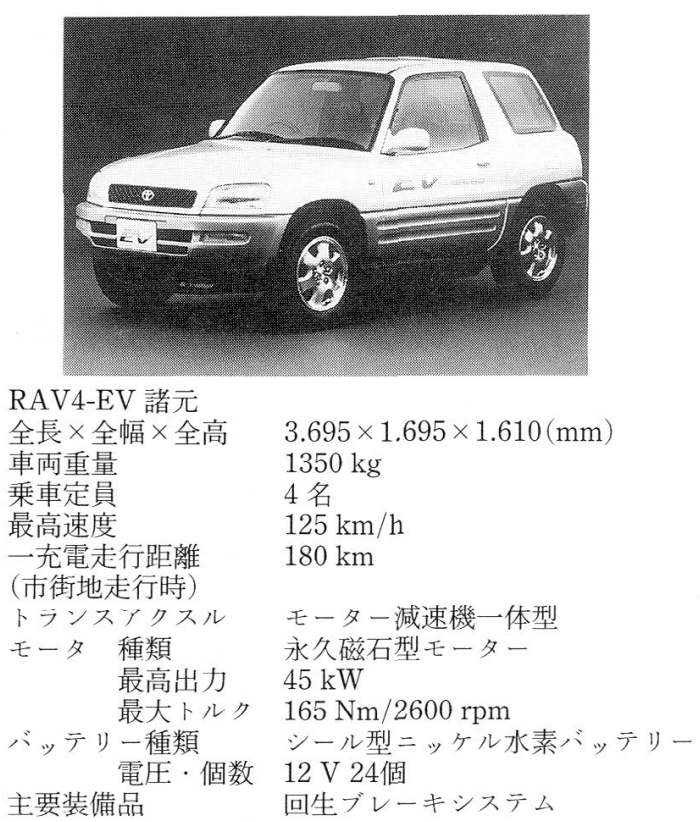

図 3 Ni-MH 電池を用いた電気自動車.

しては，車両構造の軽量化やシステムの簡素化などの種々の 方法が検討されているが，その重量の大部分を占める水素吸 蔵合金自体の性能の向上，つまり吸蔵量の増大が直接の手段 として考兄られる。

\section{2. 高容量合金開発のための基本的考え方}

水素吸蔵合金は，その発見以来，吸蔵量の増大と特性制御 に関する研究開発が行われてきた ${ }^{(3)}$. 表 2 は, このような研 究開発成果を, 水素吸蔵合金の吸蔵量と特性制御の容易さと を尺度に，大さく 3 つの世代沉分類している ${ }^{(4)}$ 。

第 1 世代合金は， $\mathrm{LaNi}_{5}$ の発見を起源とする $\mathrm{AB}_{5}$ 型合金 で，吸蔵量は，必ずしも大さくないが，その吸放出特性にす ぐれることから，小型の Ni-MH 電池に拀いて実用化されて
表 2 代表的な水素吸蔵合金.

\begin{tabular}{|c|c|c|c|c|c|c|c|c|}
\hline \multirow{2}{*}{$\begin{array}{l}\text { 世 } \\
\text { 代 }\end{array}$} & \multirow{2}{*}{ 型 } & \multirow{2}{*}{ 合金例 } & \multicolumn{2}{|c|}{ 最大吸蔵量 } & \multirow{2}{*}{$\begin{array}{c}\text { 放出条件 } \\
\text { (温度, 圧力) }\end{array}$} & \multirow{2}{*}{\begin{tabular}{|l} 
反応 \\
速度
\end{tabular}} & \multirow{2}{*}{ 活性华 } & \multirow{2}{*}{ 耐久性 } \\
\hline & & & $\mathrm{H} / \mathrm{M}$ & wt $\%$ & & & & \\
\hline 1 & $\mathrm{AB}_{5}$ & $\begin{array}{l}\mathrm{LaNi}_{5} \\
\mathrm{MmNi}_{5}\end{array}$ & 1.0 & $\begin{array}{l}0.8 \\
\sim 1.2\end{array}$ & (C) & (a) & (a) & \\
\hline 2 & $\begin{array}{c}\mathrm{AB}_{2} \\
\text { (Laves 相) }\end{array}$ & $\begin{array}{l}\mathrm{ZrMn}_{2} \\
\mathrm{TiMn}_{2} \\
\mathrm{ZrV}_{2}\end{array}$ & 1.3 & $\begin{array}{l}1.5 \\
\sim 2.0\end{array}$ & $\triangle$ & 0 & (a) & $\triangle$ \\
\hline 3 & $\begin{array}{c}\mathrm{AxBy} \\
(\mathrm{BCC} \text { 合金) } \\
(\mathrm{Mg})\end{array}$ & $\begin{array}{l}\mathrm{V}, \mathrm{Nb} \\
\mathrm{Ti}-\mathrm{V} \\
\mathrm{Mg}-\mathrm{Ni}\end{array}$ & 2.0 & $\begin{array}{l}3.0 \\
\sim 7.6\end{array}$ & $x$ & $x$ & $x$ & 0 \\
\hline
\end{tabular}

いる。第 2 世代のラーベス相構造を有する $\mathrm{AB}_{2}$ 型合金にお いては, 比較的, 容量が大きく吸放出特性にすぐれることか ら, 電池用材料として, 現在盛んに研究がす寸められてい る.これら第 1 世代, 第 2 世代の合金の研究開発において は, 図 4 亿示すよ5 亿適当な水素吸蔵サイトを有する金属間 化合物を探索し，これをべースに，単相の範囲で第 3,4 元 素を添加することにより, 格子定数を微調整して, 平衡圧を 制御する手法が用いられてきた。

これに対して，第3世代として，体心立方(BCC) 構造の 合金や $\mathrm{Mg}$ をべースとする合金群が着目されている。これ らは，吸蔵量は大きいが，常温・常王での吸放出特性がよく ない，反応速度が小さい，活性化が困難など特性制御上の問 題点が多いといわれてきた.

そこで，新エネルギーキャリアとして用いることのできる 高吸蔵量で良好な放出特性を有する合金を見出すこと，さら にはそのプロセスを新しい水素吸蔵合金の開発手法として確 立することを目的に以下のような研究を行ってきた(5)-(9).

まず，合金設計の考光方として，前述した第 3 世代の $\mathrm{BCC}$ 合金の高吸蔵量と第 2 世代のラーベス相合金の良好な 吸放出特性とを合わせ持つような「ラーベス相に関連する BCC 合金」といら新しい合金群を提案した. 


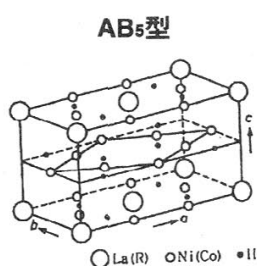

$H / M=1.0$

LaNis

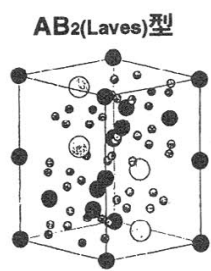

$H / M=1.33$

ZrMn2,TiMn1.5

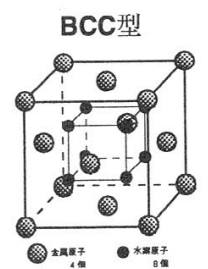

$H / M=2.0$

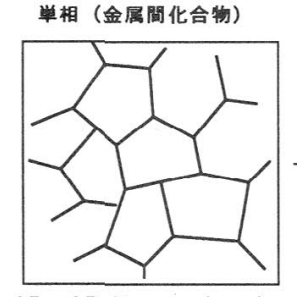

$A B_{5}, A B_{2}$ (Laves phase)

PCT 測定 $\rightarrow$ 熱力学的考察 $\mathrm{X}$ 線回折測定 $\rightarrow$ 結晶学的考察

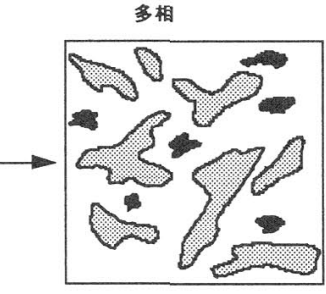

$A B_{2}$ (Laves phase) $+B C C+\ldots$. $\mathrm{X}$ 線リートベルト解析 $\rightarrow$ 金属組織学的考察
図 5 多相合金加らアプローチ.
図 4 代表的な水素吸蔵合金に打ける水素吸蔵サイト

光学 · 走査 $\cdot$ 透過電子顕微鏡

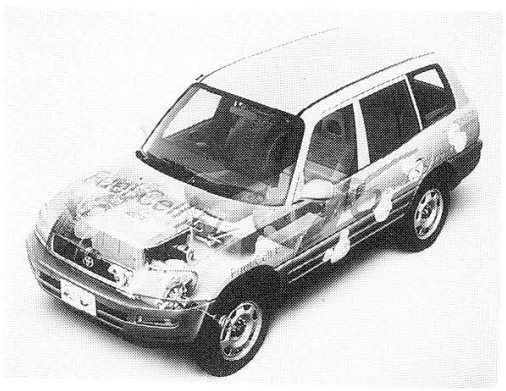

図 6 燃料電池型水素自動車.

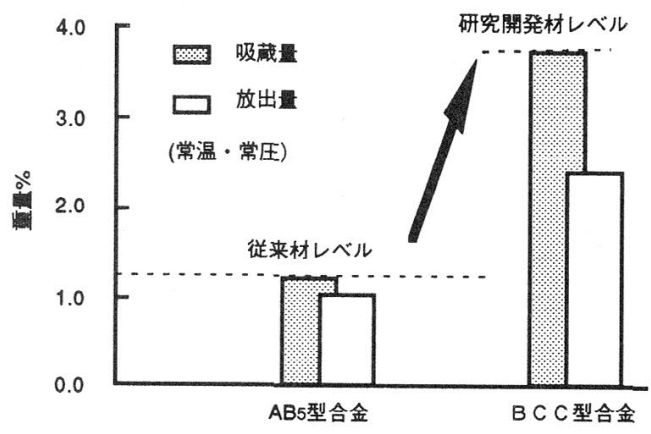

図 7 研究開発材々現状材の吸放出量比較.

\section{4. 今後の課 題}

今回開発した合金は, BCC 合金に特徵的な二段プラトー の高吸蔵量側を，常圧域にチューニングしたものである。そ のため吸蔵量の約 $40 \%$ は, 常圧で, 放出せず合金中に残っ ている、BCC 合金の中で，さらに吸蔵量を増大させるため には，低吸蔵量側のプラトを常圧域に調整するための研究が 必要である。

屯た, 応用面に打いても, 従来から提案されている水素夕 ンク, ヒートポンプあるいは Ni-MH 電池はもとより, 大き な吸蔵量や新しい機能を利用した新しいアプリヶーションの 研究を期待したい.

\section{5. 特 許}

本開発に関連する特許は，12件を出願済である。

\section{文献}

車国際シンポジウム，96/10 大阪)出品車用の合金を製造 した．図 6 に出品車両の外観を示す，図 7 には，開発合金の 水素の吸蔵・放出量を従来合金と比較して示与。開発合金の 利用可能量は従来合金の 2 倍以上で, このことにより合金 タンクをコンパクト化でき床裏に収納できた。合金は, チタ ン系の BCC 合金で，社内の既存設備を活用し製造した。吸 蔵量以外の基本性能として， BCC 合金で劣るといわれてき た反応速度や活性化のし易さについては，従来の希土類系の 合金と比較して同等レベルである。また BCC 相内部のナ， オーダーの微細組織を制卸することにより, 平衡特性のう ら，特にプラトー平坦性を制御できた。
（1）例えば, 小林博行：サンシャインジャーナル，14(1) (1993), 1 .

（2）卜ヨ夕自動車(侏)広報誌「自動車と環境」.

（3）例之ば, 大角泰章：水素吸蔵合金一七の物性と応用一, アグ ネ, (1993)。

（4）秋葉悦男：まてり㐫，35(1996)，1191.

（5）射場英紀, 秋葉悦男：日本金属学会誌，58(1994), 1225.

（6）射場英紀，秋葉悦男：日本金属学会誌，59(1995)，456.

( 7 ) H. Iba and E. Akiba; Journal of Alloys and Compounds, 231(1995), 508.

( 8 ) H. Iba and E. Akiba; Journal of Alloys and Compounds 投稿 中.

（9）射場英紀, 塩野谷美和子, 秋葉悦男：TOYOTA Technical Review, 45(1995), 108. 